\title{
Sosyal Medyada Yemek Fotoğraflarının Kimlik İnșası Bağlamında Tüketimi: Instagram Örneği
}

\author{
Gökhan DEMIREL' ${ }^{1}$ \\ Mehmet KARANFiLOĞLU23
}

\begin{abstract}
öz
Kitle iletişim araçları insanların temel haber, bilgi ve eğlence kanallarıdır. Dijitalleşmenin başlattığı değişimlerle bu araçlar değişmiş, dönüşmüş ve bünyesine yenilerini katmıştır. Sosyal medya olarak kabul edilen yeni kitle iletişim araçları insanların sosyalleşmelerinde, ilişki kurmalarında, haber, bilgi ve eğlenceye ulaşmalarında temel rolü üstlenmiştir. Yayıncı ile seyirci arasında çift taraflı iletişim sağlayan sosyal medya, içeriklerin anında değişmesini veya düzenlenmesini sağlayabilmektedir. Sosyal medyada en çok paylaşılan içeriklerin başında ise görsel içerikler gelmektedir. Özellikle de fotoğraflar, kullanıcının kendini sunma, ifade etme ve sosyal kimliğini inşa etme noktasında sıkça kullanılmaktadır. Yemek fotoğrafları bu bağlamıyla kimliğe dair oluşturulmak istenen imaja en çok katkı sağlayan öğelerden birini oluşturmaktadır. Instagram fotoğraf paylaşım özelliğiyle bu alanda kullanıcılara önemli bir katkı sağlamaktadır. Çalışma kapsamında Instagram'da \#yemek etiketi altında bulunan fotoğraflar içeriksel bağlamda incelenmiş ve paylaşımlar göstergebilimsel açıdan çözümlenmiştir. Sonuç olarak, günlük 6 milyona yakın paylaşımın büyük bir kısmının yemek ve yemek ile ilgili konulardan oluştuğu yapılan çalışmanın mikro ölçekteki örnekleminde ortaya çıkmıştır.
\end{abstract}

Anahtar Kelimeler: Sosyal Medya, Instagram, Yemek, Fotoğraf, Kimlik.

Atıf (Cite as): Demirel, G. \& Karanfiloğlu, M. (2020).

Sosyal Medyada Yemek Fotoğraflarının Kimlik İnșası Bağlamında Tüketimi: Instagram Örneği. Akdeniz Üniversitesi Illetișim Fakültesi Dergisi, 34, 236-259. D0l: 10.31123/akil.781110

1 Araştırma Görevlisi, Muş Alparslan Üniversitesi, gokhandemirel1905@gmail.com, ORCID Numarası: 00000002-6252-8383

2 Araştırma Görevlisi Dr., Hatay Mustafa Kemal Üniversitesi, İletişim Fakültesi, mehmetktr@mku.edu.tr, ORCID Numarası: 0000-0002-4895-4220

3 Sorumlu Yazar (Corresponding Author) 


\title{
Consumption of Food Photos on Social Media in The Context of Identity Construction: The Sample of Instagram
}

\begin{abstract}
Mass media are the key channel for news, information, and entertainment of individuals. With the changes initiated by digitalization, these tools have changed, transformed, and added new ones. The new mass media, social media, have played a fundamental role in socializing, establishing relationships, accessing news, information, and entertainment. Social media, which provides two-sided communication between the broadcaster and the audience, can instantly change or edit the contents. Visual content is among the most shared things on social media. In particular, photographs are frequently used to present, express, and construct the social identity of the user. In this context, food photographs constitute one of the most contributing elements to the desired image of identity. Instagram photo-sharing feature provides a significant contribution to the user in this area. In the study, photos under the \#yemek ("food" in Turkish) hashtag on Instagram were analyzed contentwise, and the posts were analyzed in semiotical. Consequently, it was revealed in the micro-scale sample of the study that the majority of the daily shares of nearly 6 million are comprised of food and food-related issues.
\end{abstract}

Keywords: Social Media, Instagram, Food, Photography, Identity.

\section{Giriș}

nsan, sosyal bir varlık olarak iletişim intiyacı duymakta ve bundan kaynaklı da insan ilişkilerinin temelinde iletişim yatmaktadır. İletişimin tarihsel sürecine bakıldığında sözlü ve sözsüz iletişim olarak iki temel ayrım ortaya çıkmaktadır. El, kol işaretleri ile ateş ve duman gibi simgesel anlatım, sözsüz iletişime örnek teşkil ederken, toplumlararası ilişkilerin ticaret, seyahat, politika ve merkezi yönetimlerle gelişmesi mektup, posta, telgraf, radyo ve televizyon gibi sözlü iletişim olanaklarını doğurmuştur.

Kitle iletişim araçları olarak kabul edilen bu araçlar zamanla teknolojik gelişmeler başta olmak üzere bir çok etmenden farklı şekillerde etkilenerek, bugün kullandığımız şekline bürünmüştür. Ancak değişim sonlanmamış ve medya araçları bugün de değişmeye devam etmektedir. Kâğıt-kalem kullanımının yerini binarik bilgisayar kodlarına bırakarak dijitalleşmesi değişimin her yere sızdığını göstermektedir. İster bilgisayarda üretilmiş olsun ister analog medya kaynaklarından gelmiş olsun, tüm yeni medya öğeleri, dijital kodlara dönüşmüş durumdadır. İnsanlar bu kodlar vasıtasıyla iletişime geçerek, duygu düşünce ve bilgi aktarımında bulunmaktadırlar (Manovich, 2001, s. 49). Bilişim teknolojileri, internet, bilgisayar ve cep telefonu alanında meydana gelen gelişmeler, medya araçlarının kodsal değişiminde başat bir rol üstlenmiştir. Bununla beraber iletişim alanında meydana gelen bir diğer önemli gelişme de akıllı telefon kullanımında yaşanan artış olmuştur. Akıllı telefonlar bir çok alanda farklı uygulamaların ortaya 
çıkmasında etkili bir araç halini almıştır. Sosyal medya da dijitalleşmenin geleneksel medyanın üzerindeki etkisinin bir sonucu olarak karşımıza çıkmaktadır. İnsanların sosyalleşme, iletişim ve ilişki kurma biçimlerinde büyük bir değişim yaratarak, insanların bu platformlar üzerinden tüm iletişim ve ilişki sürecini gerçekleştirmelerinde kolaylık sağlamıştır. Sosyal medyanın kullanım kolaylığı sunmasının yanında eğlence ve özgürlük alanı da tanıması, gün geçtikçe daha çok kullanıcıya ulaşmasında etkili olmuştur.

İnsanlar sosyal medya platformlarında tüm hayatlarını fotoğraf, müzik, metin ve resim gibi öğelerle destekleyerek başkalarıyla paylaşabilir hale gelmişlerdir. Profillerinin her biri birer vitrine veya gösteri alanına dönüşmüştür. En iyilerin paylaşıldığı, kusursuz bir imaj, zenginlik ve gösterişin yaratıldığı sosyal medya platformları, aynı zamanda bir sosyal kimlik inşa ve edinim alanına da dönüşmüştür. Sosyal medyaya yüklediğimiz her bir fotoğraf, "kimlik inşasını ve idealleştirilmiş görüntümüzü" temsil etmektedir (Şener \& Özkoçak, 2013, s. 125). Kimlik performansı fotoğrafın kendisi ve temsil ettikleriyle sınırlı değildir. Fotoğrafın üretimi, seçimi ve paylaşımı, kullanıcının belirli stratejiler ile kurduğu kendini sunum sürecinin farklı aşamalarını oluşturmaktadır. Kullanıcılar sosyal medya için özellikle çekilmiş, seçilmiş ve düzenlenmiş fotoğraflar paylaşarak imaj ve kimlik yaratım süreçlerine katkı sağlamaktadırlar. Yemek fotoğrafları ise bu anlamda güçlü bir öğe konumunda yer almaktadır. Yemek herkesin ulaşamadığı bir yerde, herkesin gidemediği bir mekânda veya herkesin sipariş edemediği bir yemek olduğunda birincil anlamından farklı bir anlam barındırmaya başlamaktadır. Mekânın ismi, yemeğin kim tarafından pişirilip servis edildiği ile nasıl sunulduğu, yemek fotoğraflarının paylaşımı için önemli birer öğe haline gelmiştir.

$\mathrm{Bu}$ çalışma ile sosyal medya üzerinde yapılan fotoğraf paylaşımlarının Instagram örneği üzerinden kimlik inşası bağlamında incelemesi yapılması hedeflenmiştir. Araştırma yöntemi olarak seçilen göstergebilimsel analiz fotoğrafların çeşitli yönlerden analizini gerektirmektedir ve ileri yapılacak olan çalışmalara ışık tutabilecek sonuçlar içermektedir.

\section{Kitle İletișim Araçlarının Dönüșü̈mü, Sosyal Medya'da Kimlik İnșası ve Tüketim}

Bir mesaj iletimi söz konusu olunca mağara resimlerinden bugün kullandığımız emojilere kadar uzanan bir tarihsel süreçten bahsetmek gerekir. Mağara duvarına ilk resmi çizen kişi ile bugün cep telefonundan durumunu izah eden bir emoji gönderen kişi aynı amacın paydaşıdırlar. McLuhan'ın ifadesiyle dünyayı "global bir köye" çeviren gazete, radyo ve televizyon gibi analog medya araçları, Işık’a (2012, s. 19) göre kitle iletişim araçları olarak kabul edilmektedir. Bu araçlar, iletilerin kitlesel üretim ve dağıtımını gerçekleştirmekte etkili olmuşlardır.

Analog medya araçları, uzun yıllar boyunca kitlelere iletilecek mesajların tek taraflı kontrolüne sahip olmuşlardır. Kanallar belirli bir zümrenin denetiminden tüm kitlelere yönlendirilmekteydi ve kitle mesajın içeriğinde, düzenlenmesinde veya paylaşımında söz sahibi değildi. Ancak 20. yüzyılın başlarında yeni iletişim imkanlarının ortaya çıkmasıyla iletişim süreci tamamen değişerek bambaşka bir boyut kazanmaya 
başlamıştır. Teknolojik bağlamda yaşanan hızlı ilerleme, yüz yüze iletişim modelini değiştirmiştir (Barnes, 2006, s. 2). Özellikle de ikili ilişkiler temelinde meydana gelen değişimler, insanların sosyalleşme pratiklerini dönüştürmüş ve yeni bir iletişim yönteminin doğmasını sağlamıştır. İnternet, bilgisayar ve akıllı telefonların daha çok kişi tarafından kullanılmaya başlanması bu süreçte etkili olmuştur.

Yeni iletişim biçimi ile eskisi arasındaki en büyük ayrımın maliyet, kurumsallık, depolama, kalifiye iş gücü ve ileti kontrolünde yattığı söylenebilir. Analog dönem medya araçlarında kaynağın bir kişi değil de bir kurum olması gerekmekteydi. Ayrıca bireysel yayın yapma imkanı olmadığı gibi yayınlama işi, bir kişinin değil bir ekip çalışmasının neticesinde meydana gelebilmekteydi. Ancak yeni medya formatında bireyler tek başına, herhangi bir mekan sınırlaması olmadan yayın yapma imkanı elde etmiştir. Analog dönemde yüksek maliyetli yayın ekipmanları ile yayınların fiziki olarak geniş bir mekana intiyacı, yeni medya döneminde ortadan kalkmıştır. Bilişim alanında yaşanan gelişmeler, medya sektöründeki harcamaların azaltılmasında önemli rol oynamıştır (Toplu, 2008). Bugün sınırlı olanaklarla oldukça etkin yayıncılık yapılabilmektedir. Uydu teknolojileri ve internetin gelişmesi karasal yayıncılığa olan intiyacı azaltmıştır. İnternet ve uydular aracılığıyla yayınların gerçekleşebildiği yazılı, işitsel ve görsel medya sektöründe, uluslararası düzeyde erişilebilirlik sıradan bir hal almıştır. Bireyler, sadece cep telefonundan bile istediği yerden ve istediği zaman yayın yapabilme imkanı elde etmiştir. Yeni medya biçiminde her bir veri, dijital kodlar şeklinde bulut teknolojisinin sunduğu alanlarda depolabildiği için kullanıcı, istediği zaman ve istediği yerden verilere herhangi bir engel olmadan erişim imkanına bulmuştur.

Analog medya ile dijital medya arasındaki bir diğer en önemli ayrım, yayıncı ile izleyci arasındaki iletişim biçiminin değişmiş olmasıdır. Analog dönemde yayıncı aktif izleyiciler ise pasif bir konumda yer alırken, yeni medya biçiminde hem yayıncı hem de izleyici aktif bir iletişim sürecine geçiş yapmışlardır. Evans, analog medya araçlarında kullanıcılara başkalarının denetiminden geçen içeriklerin iletildiğini ve iletimin tek taraflı yapıldığını vurgularken, dijital medyanın kullanıcıyı sürece kattığını belirtmektedir. Kullanıcı aldığı veya alacağı mesaja müdahale edebildiği interaktif bir iletişim biçimine girmiştir (2008, s. 80). İletişim, tek taraflı bir biçimden, çift taraflı bir biçime doğru evrilmiştir. Mesajı ileten de mesajı alan da iletişim sürecinin tüm noktalarında istediği oranda söz sahibi olabilmektedir. Kaynak ile alıcı arasında karşılıklı beğeni ve yorum ile interaktif bir iletişim kurulmuştur. İçerikler anında düzenlenebilmekte, değiştirilebilmekte hatta yayından kaldırılabilmektedir.

Sosyal medya bu bağlamıyla kullanıcıyı oldukça aktif bir iletişim sürecine dahil etmiştir. Sosyal medyanın çevrimiçi tabanlı olması kullanıcıya hız, zaman ve mekân bağlamında avantaj ve kolaylık sağlamıştır.

Sosyal medya, modern insanın büyük oranda bilgi, eğlence ve haber kaynağını oluşturmaktadır. Bunun yanında sosyalleşme, ikili ilişkiler de aynı şekilde bu platformlar üzerinden gerçekleşebilmektedir. Boyd ve Elison sosyal medyayı insanlara profiller oluşturarak içerik üretmelerinde yardımcı olan ve bu içerikleri oluşturulan arkadaş listeleriyle paylaşma imkanı sağlayan alan olarak tanımlamaktadır (2008, s. 211). Sosyal medyada içeriklerin istendiği zaman düzenlemeye veya güncellemeye açık 
olması, sosyal medyanın kullanışıı bir alanını oluşturmaktadır. Kullanıcı kendi içeriğini istediği zaman, istediği şekilde düzenleyip tekrar paylaşabilmektedir.

İçerik, kullanıcının sahip olduklarını sosyal medyada paylaşmasıyla oluşmaktadır. İçeriklerin diğer kullanıcılar tarafından tepki alması, kullanıcıların içerikleri aracılığı ile hem içerik üreticileriyle hem de birbirleri ile etkileşimde olması önemlidir. Dolayısıyla kullanıcı özenli davranarak içerik üretir ve paylaşır, ürettiği her bir içerik kimliğine dair ipuçları vereceğinden hiçbir içerik rastgele seçilerek paylaşıma sokulmamaktadır. Özdemir, kullanıcıların sosyal medyada içerikleri sayesinde görünür olduklarını ve bu içeriklerin kimlik ve benlik yaratımında etken olduğunu belirtmektedir (2015, s. 113). Görünürlük, etkileşim sağladığından, benlik oluşumuna etkileşimin kendisi bizatihi katkı sağlamaktadır. İnsanların neye sahip olduklarının önemi ise ancak başkaları tarafından da biliniyorsa ve görünüyorsa bir değere dönüşebilmektedir. Dolayısıyla görünürlük elde etmek, beğeni almak, taktir toplamak ve onaylanmak, sosyal medya paylaşımlarının temelini oluşturmaktadır. Horzum-Taylor, insanların sosyalleşirken diğerlerinin takdir, beğeni, sevgi, saygı ve onayına ihtiyaç duyduğunu ifade etmektedir (2015, s. 1220). Kullanıcı onay almak adına, sahip olduklarını sosyal medyanın sunduğu imaj yaratım alanında sergilemektedir. Ancak sosyal medyanın denetimsiz (istenilen şeyin istenildiği şekilde paylaşılabilmesı), sınırsız (istenilen ölçüde çevrimiçi olma) ve zamansız (istenilen her zaman çevrimiçi olabilme) olma özellikleri, kullanıcının aynı zamanda sahip olduğundan farklı bir kimliğe bürünebilmesine de neden olabilmektedir.

Sosyal medyada yüzyüze iletişim zorunluluğunun olmaması, kullanıcıya paylaşım yaparken, kimlik yaratırken veya olmak istediği kişi olurken rahatlık ve cesaret vermektedir. Özdemir, gerçek kimliğini sergilemesindeki engelin, kişinin başkalarınca beğenilme isteğine bağlamaktadır. Kişi, kendinde noksan gördüğü noktaların oluşturmak istediği kimliğe uymayacağının fakındadır (2015, s. 127). OImak istenen kişi ve kimliğe bürünürken, istediği imajı yaratırken bunu resim, fotoğraf, kişisel bilgiler, pahalı, lüks ve farklı tüketim ürünleriyle destekleyebilmektedir. Bu bilgilerin doğru olma zorunluluğu yoktur, önemli olan kullanıcının neyi sunduğudur. Arık, kullanıcıların yeni medya uzamları sayesinde istedikleri kimlikleri yaratma olanağı bulduğunu belirtmektedir. Bu süreçte de popülerlik, görünürlük, beğenilme ve taktir edilme ön planda tutulmaktadır (2013, s. 104). Arzulanan bir kimliğin inşasına giden yol ise tüketim ve sunum gerektirmektedir. Diğer bir ifadeyle kimlik yaratım süreci imaj, prestij, gösteriş ve tüketim üzerine kuruludur. Özdemir, sosyal medyanın kullanıcıyı kimlik performansına sürüklerken, onu paylaşım, beğeni ve yorum ile sürekli aktif ve etkileşimde kalmaya zorladığını belirtmektedir. Etkileşim, kullanıcıya ilişkin ipuçları vererek kimliğin diğer kullanıcılara aktarılmasında etkilidir. (2015, s. 121).

Kullanıcı, oluşturmak istediği kimliğe ait güçlü bir imaj yaratmak adına başkalarına göstereceği, sürekli bir tüketime yönelmek zorunda kalabilmektedir. Bu tüketime pahalı kıyafetler, lüks ürünler, yüksek maliyetli etkinlikler, parti ve tatiller dahildir. "Sosyal medyada yansıtılan kimliğin, tüketim araçlarıyla meşrulaştırılması çabası da bireylerin birer tüketim nesnesine dönüşmesi ile sonuçlanmaktadır" (Özcan-Demir, 2017, s. 285). Hatta kullanıcı kendi bedenini bile bir tüketim öğesine dönüştürerek insanların beğenisine sunabilmektedir. Baudrillard, diğer tüketim nesneleri arasında bedenin en güzel ve değerli tüketim nesnesi olduğunu ifade etmektedir (2017, s. 163). 
Bu bağlamıyla güzellik ve beden politikaları, şık kıyafetler, takılar, dövmeler makyaj, estetik kaygılar ve davranışsal normlar beden tüketimine örnek teşkil etmektedir. Zira tüketim sadece maddi malların tüketimi ile sınırı bir eylem değildir. Özellikle de sosyal medya ile birlikte tüketim biçimleri oldukça farklılaşmıştır.

İnsanlar artık sadece tükettikleri üzerinden değil, tükettiklerini gösterip göstermedikleri üzerinden de değerlendirilmektedir.Varlık, ancak sosyal medyada varsa kabul edilebilir hale gelmiştir. Fotoğraf ise varlığı göstermenin en kolay, etkin ve yaygın yolu olarak kullanılmaktadır. Fotoğraf, ötekilerin gözünde varlığın somut kanıtını oluşturmaktadır (Lasen \& Gomez, 2009, s. 215). Sosyal medyada kişi fotoğraf paylaşarak kendi varlığını görünür kılmaktadır. Diğer bir ifadeyle yapılan her bir harcamanın, etkinliğin, kutlamanın, yemeğin, tatilin hatta taziyenin paylaşılmaması, yok sayılması ile eşdeğer tutulmaktadır. Öyle ki sosyal medya için özellikle pozlar düşünülmekte, etkinlikler, kutlamalar partiler verilmektedir. Bu organizasyonlar neticesinde yapılan paylaşımlar sıradan veya özensiz değillerdir. Aksine kullanıcı fotoğraf aracılığıyla kimlik performansı yaparken belirli stratejiler izlemektedir (Şener \& Özkoçak, 2013, s. 126). Sosyal ağlarda yer alan fotoğrafların pek azı rastgele çekilip yüklenmiştir. Bu fotoğraflar, genellikle kasıtlı olarak kurgulanmış, modelin ve fotoğrafçının bir dizi tercihi sonucunda gerçekleştirilen fotoğrafik bileşenlerden ve etkinliklerden oluşmaktadır. Gösteriş, beğeni ve onay söz konusu olunca sıradanlık ve rastgele paylaşım düşük bir intimal olarak yerini koruruken, paylaşımlar biz dizi düzenlemeden geçtikten sonra profil sayfalarında yer almaktadır.

Tasarı sonucuda yapılan her paylaşım, beraberinde bir beklentiyi de doğurmaktadır. Beklenti, yüksek beğenme ve yorumlanma şeklinde olurken, bunun ön koşulunu ise farklılık oluşturmaktadır. Özellikle de gösteriş tüketiminde, tüketilen şeyin bir değer oluşturması için herkesin sahip olamayacağı bir öğeden oluşması gerekir. İnsanların satın alamadığı pahalı ve tasarım bir kıyafet, bilet bulamadığı özel bir etkinlik, bir davet veya lüks bir restoranda yemek ayrıcalık oluşturup ilgi doğuracağından insanların ilgisini daha çok çekmektedur. Bunun da paylaşım adına bir değer oluşturduğunu ifade etmek mümkündür.

\section{Yemek Fotoğraflarının Paylașımı ve Instagram}

Bir fotoğraf paylaşım uygulaması olan Instagram, dünya genelince en çok kullanıcı sayısına sahip başlıca uygulamalar arasında yer almaktadır. Statista analiz sitesinin verilerine göre 2020 yılında Instagram, 1 milyon kullanıcı sayısını aşmış durumdadır (Clement, 2020). Sınırlı karakterlerle yazı yazmaya olanak tanıyan mikrobloglar, yer bildirimi üzerine inşa edilmiş uygulamalar, dublaj ve karaoke uygulamaları gibi farklı alanlarda gelişen bir çok uygulama mevcuttur. Instagram da bu uygulamalardan biri olarak, özellikle fotoğraf paylaşımı üzerine gelişme göstermiş bir uygulama olarak dikkat çekmektedir.

Instagram, yüksek kullanıcı sayısına sağladığı kullanım kolaylığı ve uygulamanın bünyesinde ücretsiz sunduğu filtreler sayesinde erişmiştir. Sosyal medya, vasıfsız insanlara fikirlerini beyan edecekleri bir alan sunduğu için, insanlara kendilerini önemli 
hissettirmektedir (Eldeniz \& Sepetci, 2017, s. 226). Instagram sayesinde de kullanıcı herhangi bir fotoğraf bilgisi olmadan, profesyonel ayarlara yakın düzenlemeler yaparak, fotoğrafını anından paylaşma imkanı elde etmiştir. 2010 yılında Kevin Systrom ve Mike Krieger isimli iki girişimci tarafından geliştirilen Instagram, daha sonra dünyanın en çok kullanıcı sayısına sahip uygulaması olan Facebook tarafından satın alınmıştır (Şener E. , 2012). Uygulama, sürekli güncellenerek bünyesine bir çok yeni özellik ve farklı filtreler eklemeye, kullanıcı deneyimlerini arttırmaya devam etmektedir. Bunun yanında uygulama video paylaşımını, fotoğraflara yer bildirimleri ve etiket eklemeyi ile yorum ve beğenmeyi kullanıcıların hizmetine sunmuştur.

Görsel öğeler, sosyal medyada en çok paylaşılan içeriklerin başında gelmektedir (Herhold, 2019). İnsanlar neredeyse gündelik hayatlarında önemli veya önemsiz gördükleri bir çok olayı fotoğraflayarak sosyal medyada paylaşmaya başlamışlardır. Bu da sosyal medyanın görsel dil temelli ağlardan oluştuğunu göstermektedir. Özellikle de Instagram, bu dili doğrudan kullanan bir uygulama olarak dikkat çekmektedir. Instagram, Polaroid makinenin efektlerini dijital olarak kullanan bir telefon uygulamasıdır (Yetkin-Cılızoğlu \& Çetinkaya, 2016, s. 169). Uygulama, fotoğraflara anından filtre uygulanarak paylaşılmasında oldukça kolaylık sağlamaktadır. Fotoğraflara etiketlerin iliştirilebilmesi, fotoğrafları daha güzel, etkili ve eğlenceli hale getirmeye yarayan uygulama içi araçların olması ile anasayfanın bir vitrin ve fotoğraf albümü gibi kullanılması uygulamaya kullanıcı kazanımda katkı sağlamaktadır. Instagram'ın geniş kullanıcı sayısı, diğer uygulamalara kıyasla daha genç ve daha çeşitli kitlelerden oluşmaktadır (Salomon, 2013, s. 408). Böylece kullanıcılar, paylaştıkları fotoğraflara farklı gruplardan etkileşimler alabilmektedir. Beğeni ve yorumlama, fotoğrafın iyi ya da kötü olmasına kriter haline gelmiştir.

Fotoğraf, tüketimin gösterisi halini almışken, Instagram ise bu gösterinin merkezi haline dönüşmüştür. İnsanlar neredeyse tükettikleri her şeyi paylaşır hale gelmişlerdir. Instagram insanların yaşadıklarını, eğlendiklerini, gezdiklerini, sosyal faaliyetlerde bulunduklarını gösterdikleri mekana dönüşmüştür. Bugün insanlar, analog imaj çağına kıyasla kimliklerini oluşturmak için fotoğraflara güvenmektedir (Winson, 2013, s. 9). Dahası, gerçeklik kavramlarını yaratmak için giderek daha fazla çevrimiçi görsele yönelmektedirler. Yemek fotoğrafları da en çok bu alanda kendine yer edinmeye başlamıştır. Gösteri tüketim gerektirdiğinden, sosyal medyada kimlik inşası, doğrudan gösteriş temelli bir tüketime indirgenmeye başlanmıştır.

Tüketim, fizyolojik ve psikolojik intiyaçların tatminine dayalı bir eylemdir. Fizyolojik intiyaçlar, bedenin sağlıklı bir şekilde varlığı için gerekliyken; psikolojik ihtiyaçlar, ruhun doyumu için gerekli görülmektedir. Sağlıklı bir birey için bu iki ihtiyacın da yeterli oranda tatmin edilmesi gerekmektedir. Ancak tüketimin günümüzde kazandığı sembolik anlamlar, bu iki temel intiyaç arasındaki çizginin belirsizleşmesine neden olmuştur.

Yemek fotoğrafları, bu anlamda önemli bir gösterge değerine sahip olmuştur. Günlük deneyimleri birleştirmek ve paylaşmak için bir köprü görevi gören yemek fotoğrafları, ruhun tatminini sağlayacak sembolik bir anlam kazanmıştır (Ibrahim, 2015, s. 46). İnsanlar önlerine gelen yemeği, gösteri değeri ve estetik kaygılardan dolayı, tatmadan önce fotoğraflayarak sosyal medyada paylaşır hale gelmişlerdir. Tadımdan önce 
paylaşım, fizyolojik değil psikolojik tatmine yönelik bir işarettir. Sosyal medyada en çok paylaşılan fotoğraflar arasında yer alan yemek, bir sembol halini alarak, günümüzde bazı insanların nazarında artık kendini tanımlamaya dönüşmüştür (Kocabay, 2014, s. 73). Tükettikleriye "görünürlük" elde eden günümüz insanın yemek mekanı tercihleri de bu yönde olmaktadır. Sosyal medya bu anlamda kullanıcılara bir alan sunmaktadır. Üstelik artık sadece yemeğin kendisi değil, yemeğin mekanı, yemeğin servis şekli ve yemeğin sunumu bir gösteri değeri taşımaktadır. Paylaşılan fotoğrafa gelen tepkiler ise ruhun ihtiyacı olan haz ve tatmine örnek teşkil etmektedir.

Sosyal medyada yemek fotoğrafı paylaşmak için o yemeğin bir gösteri değerinin olması gerekmektedir. Tadından ziyade sunumun ön plana çıktığı sosyal medya platformlarında bir metanın gösteri değeri, her şeyin üstünde tutulabilmektedir. Gösteri değerini arttıran etmenler ise yemeğin kendisi, mekanın kendisi, yemeği kimin yaptığı ve sunumdaki farklılık ile yemeğin kiminle yendiği gibi bilgilerdir. Dolayısıyla sosyal medyanın geniş kullanıcı kitlesi ve yayılım alanı, sadece bireysel kullanıcılar için değil restoran sahipleri için de bir gösteri alanına dönüşmüştür. Günümüzde insanların yemek yemek ve sosyalleşmek adına tercih ettikleri mekanların Instagram'a uygunluğu önemli bir kriter haline gelmiştir (Öksüz, 2019, s. 1316). Müşterilerin gittikleri güzel mekanları sosyal medyada paylaşma istekliliği, mekanların bu beklentilere cevap verecek şekilde çalışmalarına yol açmıştır Mekanlar da yemeklerini farklılaştırmak adına, farklı konseptler geliştirmeye çalışırken, gösteri ve şov değerini ön planda tutmaya başlamışlardır.

Yemek fotoğrafları sıradan değil lüks, marka ve ünlü olan yerlerde çekildiğinde bir prestij, statü ve gösteriş simgesine dönüşebilmektedir. Sıradan bir restoranda yenen sıradan bir yemek, farklılaşma adına herhangi bir değer oluşturmadığından, sosyal medyada paylaşılmaya da değer bulunmamaktadır. Sosyal medya paylaşımlarında her yemek ve her sunum yer almamaktadır (Kocabay, 2014, s. 77). Kullanıcı, yemek fotoğrafını paylaşırken yemeğin mekânı ve sunum estetiği gibi kıstasları göz önünde tutmaktadır. Birey, gidebildiği lüks yerleri, yiyebildiği lüks yiyecekleri arkadaşlarına göstererek, kendine kimlik ve statü kazandırmayı hedeflemektedir. Dolayısıyla sosyal medyada etkileşim alma intimalinin yüksekliği, bir yemeğin temel paylaşım değerini oluşturan etmen olarak dikkat çekmektedir. Sahip olabildiğini göstermenin en kolay yolu da fotoğraflar ile bunun sosyal medyada belgelenmesidir. Yemeğin sosyal medyada paylaşılmasında temel, yemeğin kendisi değil verdiği mesaj, sağladığı satatü sunduğu ikincil faydalardır. Chung ve arkadaşları, insanların Instagram'da yemek paylaşırken bunu yediklerini kaydetmek, sosyal bağlamda onay almak ve aynı şekilde onay sunmak amacıyla yaptığını ifade etmektedir. (2017, s. 1674). Bir yemek fotoğrafına takipçilerden gelen yorum ve beğeniler, yemeğin tadının, lezzetinin önüne geçebilmektedir. Aslolan tadım değil, gösterinin kendisidir. Paylaşılan da lezzet ve tat değil gösteriş, dış görünüş, servis şekli ve sunumdur.

Özetle, yemek fotoğrafı paylaşımı bireyleri "tüketebiliyorsam varım" düşüncesi ile güdüler hale getirmiştir. Bireyler yemekleri sosyal medyada teşhir ederek, bu yemekleri alabilecek sosyo-ekonomik ve kültürel camiada yer aldıklarını ispat etmektedirler. Ait olmak istedikleri cemiyeti işaret ederek; "bu yemekleri tüketebiliyorum", "bu yemekleri satın alabiliyorum" mesajlarını iletmektedirler. 


\section{Instagram'da Paylașılan Yemek Fotoğraflarının Göstergebilimsel Olarak Incelenmesi}

Bu çalışma, sosyal medyada paylaşılan yemek fotoğraflarının bireylerin Instagram profiline estetik açıdan katkısının olup olmadığı, bireysel imajlarına neler yaptığı ve paylaşımların tüketim ile ilişkisinin nasıl olduğu fikrinin tartışıması sonucu yapıımıştır.

\subsection{Araștırmanın Amacı}

Mevcut toplumsal yapıda tüketimin intiyaçtan ziyade daha çok prestij kazanma, farklı olma, imaj kaygıları giderme, kimlik oluşturma, bir zümrete dahil olma ve/ veya bir üst zümreye geçme gibi nedenlerle yapıldığı iletilmektedir (Bayar, 2012, s. 322-323). Dolayısıyla tüketim toplumlarının tüketme alışkanlıklarının gerekçeleri önceki dönemdekilerden oldukça farklılaşmıştır. Tüketmenin var olmak ile doğrudan ilintilendirildiği böylesi bir dönemde sosyal medyanın da bu amaçla kullanılması kaçınılmaz olmaktadır. Tüketilenin teşhir edilmesi, onun kullanım değerinden ziyade gösterge değeri ile ilintilendirilmektedir (Özcan, 2013, s. 134).

$\mathrm{Bu}$ çalışmada, fotoğraf paylaşım uygulaması olan Instagram'da genelde tüm paylaşımların, özelde ise yemek fotoğraflarının kişinin imaj ve kimlik yaratım sürecine katkı sağlayıp sağlamadığınının araştırılması ve yemek fotoğraflarının paylaşıımasının altındaki nedenlerin öğrenilmesi amaçlanmıştır.

\subsection{Araștırmanın Yöntemi: Göstergebilimsel Bakıș}

Dil, organik bir varlık olarak sürekli gelişme göstermektedir. Dil'in anlatı yapısı tek ve biricik değildir. Dilde imgesel ve soyut bir dizilim söz konusudur. Bir kavram tek bir anlamda kullanılmadığı gibi aynı anda hem somut hem de soyut bir varlığı işaret edebilmektedir. Burada dilin doğrudan doğruya hem kültür ile bağlantılı olması hem de kültürün taşıyıcılığını yapması etkili olmaktadır.

İmge, dil ile ifade edilen somut bir nesnenin soyut anlatımıdır. "Dil ile imge ayrılmaz şekilde birbirine bağlanmıştır” (Burnett, 2007, s. 92). Dilsel anlamlandırma için kültürel bir altmetne intiyaç duyan imge, doğal olarak değişkenlik göstermektedir. Kültürün oluşturduğu değerler, kişinin beslendiği her şey, anlamsal değişkenlere etki etmektedir. "Kültürel düzende, bizi çevreleyen her şeyin bir göstergeyi işaret ettiği bilinmektedir. İmge bu göstergelerin dolayımından oluşmaktadır. İmge kavramı gerçekliğin yeniden üretilmesi ya da yorumlanması diye tanımlanabilir" (Uysal, 2011, s. 3). Anlamlandırma veya imgelem, bireyin beslendiği kültürel ve toplumsal kaynaklardan, kavramları süzerek zihninde canlandırmasıdır. Göz önünde olanın, gösterilenin farklı bir algılanışının ortaya çıkmasıdır. Bir diğer ifadeyle görünenin ardındaki anlam, imgeyi temsil etmektedir.

Roland Barthes'ın göstergebilim kuramı imgelemin metaforik anlatısına çözümleme getirmektedir. Barthes, göstergebilimi 'Gösterge, Gösteren ile Gösterilen” arasındaki 
ilişki temelinde incelemektedir. Ancak göstergebilimin temellerini atan, Ferdinand de Saussure'dir. Saussure, gösterbilimi dilsel bağlamda incelemiştir. Barthes ise Saussure'ün kuramını geliştirerek, göstergebilimin görsel anlam çözümlemelerinde kullanımasının önünü açmıştır. Barthes, kendi kuramını açıklarken göstergebilimin temelde iki bağıntı varsaydığını ve bu bağıntının da iki farklı türden nesneyi kapsadığını belirtmektedir. Bunlar da eşitlik değil, denklik getirmektedir. Ancak Barthes, yalnızca gösterenin gösterileni belirten dilbilimin aksine, her türlü göstergesel dizgede iki değil, üç farklı terimin karşısında bulunduğunu ifade etmektedir. Çünkü kavradığım şey, art arda gelen birer terim değil, kendilerini birleştiren bağıntıdır, der. Bu noktada Barthes göstereni, gösterileni ve bu iki terimin çağrışımsal toplamı olan göstergeyi öne sürmektedir (1990, s. 158). Barthes'ın göstergebilim şeması şekil 1'de gösterildiği şekildedir (Bircan, 2013, s. 23):

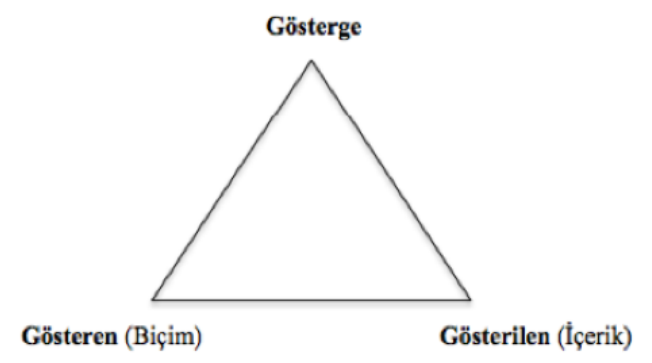

Şekil 1. Barthes'ın Gösterge Şeması

Göstergebilim imge, yani göstergenin bireysel düzeyde zihinsel izdüşümünü ifade etmektedir. Göstergebilim anlamlandırmayı kültürel kodlar aracılığıyla gerçekleştirmektedir. Burnett, bir imgenin ancak kişinin geçmişine, kültürüne, bilgisine veya hayallerine dokunması sonrasında anlamlı hale geleceğini ifade etmektedir. (2007, s. 40). Burnett'in tanımında, kültürel kodların anlamlandırmadaki önemine vurgu yapılmaktadır.

Göstergebilim, dilin her bir kelimeye kendi dışında yüklediği anlamın peşindedir. Ancak dilbilim söylemin büyük parçaları altında anlam taşıyan nesnelerle uğraşırken, göstergebilim dilbilimin bir bölümü olarak söylemin anlamlı büyük birimlerini üstlenmektedir (Bircan, 2013, s. 21). Bu anlamlar, söylenenin gizil anlamlarıdır. Renkler, şekiller, jest ve mimikler ile alışagelmiş davranışların tümü, gizil anlamın öğeleridirler ve mesaj iletiminde alıcıda farklı biçimlerde kavramsallaştırılmaktadır. Barthes gösterileni, göstergeyi kullanan kişinin ondan anladığı 'şey' olarak açıklamaktadır. Böylece salt işlevsel bir tanıma ulaşmış oluruz, der. Gösterilen, göstergenin bağlantısal iki öğesinden biridir. Onu gösterenin karşıtı yapan tek ayrım ise gösterenin bir aracı kimliği taşımasıdır (1979, s. 35). Kişi vermek istediği soyut kavramları, somut bir nesne üzerinden verebilmektedir. Göstergebilimin gücü, tek bir göstergenin bir çok farklı gösterilene varmasından gelmektedir.

Edgar-Hunt, göstergebilimin fiziksel ve psikolojik iki ayrı yanının olduğunu belirtmektedir. Bir gösterge olan fiziksel yan, görülebilen, duyumsanan somut yandır. Psikolojik yan ise alıcının zihninde canlanan şeydir. Gösteren, göstergenin anlaşılan kısmı, gösterilen ise 
göstergenin alıcı için asıl olarak taşıdığı anlamdır. Göstergebilim, kendisinden başka bir anlamı, benzerlikler ve altmetinler kullanarak oluşturan nesnelerin dilidir. Görünen nesnenin görünmeyen ancak iletilen mesajını çözümler. Göstergebilim gizil mesaja düzanlam/yananlam arasındaki ilişki bağlamında ulaşır. Düzanlam, göstergenin dolaysız, doğrudan en bilinen anlamıyken, yananlam ise göstergenin ikincil yani dolaylı anlatımıdır. Göstergenin alıcıda akla ilk getirdikleridir (2010, s. 24-26). İki anlam arasındaki ilişki, düz ifade edilen bir şeyin yan anlamında ne olduğuyla ilgilidir.

Dolaylı anlatım, dolaysız anlatımdan daha güçlü olabilmektedir. Görüntü tek bir iletimden sorumluyken, ardıı bir çok farklı anlamdan sorumludur. İmgenin canlandırdıkları için "kendisi o şey olmadığı halde, o şeyi çağrıştırarak iletişimde bulunan şey" (Parsa \& Parsa, 2012, s. 15) ifadesi kullanılmaktadır. Kişinin gördüğü imge, benliğinin inşasında yer alan kültürel ve bilişsel taşlar kadardır. Dolayısıyla düzanlamın ardılı olan yananlam, kişinin baktığı açıya hatta baktığı zamana göre değişkenlik göstermektedir. İmge, gösterilen şeyler değil, birer temsil veya yeniden sunumdur (Leppert, 2009, s. 16). İmgeler dünyayı değil, dünyalardan bir dünyayı göstermektedir. İmge, insan bilincinin kültürle yoğrulmuş bir ürünü olarak, zamansal ve kavramsal anlam farklılıklarına sahiptir. Göstergebilim de insan eylemlerinin altında, bilinçli veya bilinçsiz, yatan imgesel anlamı sorgulamaktadır.

Bu çalışmada Instagram'da yemek paylaşımları, fotoğrafı paylaşan kişinin kimliği (profil sayfası), fotoğrafın taşıdığı estetik kaygılar ile fotoğrafın çekildiği mekan ve paylaşıma iliştirilen etiketler, Roland Barthes'ın göstergebilimsel analizi bağlamında çözümlenmiştir. Çalışmanın örneklem alanı makalenin sınırları gözönüne alınarak 1 hafta (7 gün) olarak belirlenmiştir. Veriler, haftanın ilk gününden haftanın son gününe (Pazartesi-Pazar) kadar geçen zamanda her gün, gün dönümü olan saat 00:00'da \#yemek etiketiyle yapılan aramada çıkan toplam paylaşım sayısı olarak belirlenmiştir. Bu paylaşımlardan ise en günceli yakalamak adına, paylaşılan en son 10 veri çalışmaya dahil edilmiştir.

Paylaşımlar beş ana başlık etrafında analiz edilmiştir. Buna göre; tema başı̆̆ı altında, paylaşımın yemek ile mi ilgili olduğuna, yoksa yemek etiketiyle paylaşılmış farklı bir görsel mi olduğuna, Kullanıcı başlığı altında, paylaşımın bireysel kullanıcı profiline mi ait olduğuna, yoksa maddi kazanç sağlamak amacıyla açılan bir sayfa mı olduğuna, Çekim başıı̆ı altında, fotoğraf/video'nun profesyonel çekim mi yoksa amatör çekim mi olduğuna, Ön Plan başlığı altında, paylaşımda dikkat çekilmek istenenin yemeğin kendisi mi, etiketlenen bir mekan mı yoksa bir insan mı olduğuna, Estetik baş/ığı altında, ise paylaşımın estetik kaygılar güdülerek mi yoksa rastgele bir şekilde mi yapılmış olduğuna bakılarak detaylandırma yapıımıştır. Ayrıca makalenin temel paylaşım öğesi 'yemek' olduğundan Tema başlığı altında paylaşımların hepsi ele alınmışken, diğer başlıklarda sadece yemek ile ilgili olan paylaşımlar dikkate alınmıştır.

\subsection{Araștırmanın Bulguları}

Araştırma bulguları tablo 1'e göre; 1. günde, hem 'Başlıca' hem de 'En Yeni' başlığı altında 20 paylaşım ele alınmış, bunlardan 17'si yemek ile ilgili paylaşımlardan 
oluşuyorken, 3 tanesi yemek ile ilgisi olmayan paylaşımlardan oluşmuştur. Yemek ile ilgili toplam 17 paylaşımın tümü yemek ve mekan adına açılan sayfa profilleri tarafından yapılmıştır. Fotoğraflardan 9 tanesi profesyonel şekilde çekilmişken, 8 tanesi ise amatör çekim şeklinde olmuştur. 17 paylaşım içinden 12 tanesinde vurgulanan yemeğin kendisiyken, 3 tanesinde mekan, 2 tanesinde ise insan şeklinde olmuştur. Estetik kaygılar güdülerek çekilen fotoğraf sayısı ise 17'de 8 olarak tespit edilmiştir.

Tablo 1. 7 Günlük Instagram Verileri

\begin{tabular}{|c|c|c|c|c|c|c|c|c|c|c|c|c|c|c|c|}
\hline \multicolumn{2}{|c|}{$\begin{array}{c}\text { Gün ve } \\
\text { Paylaşım sayısı }\end{array}$} & \multicolumn{2}{|c|}{$\begin{array}{l}\text { 1. Gün } \\
5.7 \mathrm{M} \text {. }\end{array}$} & \multicolumn{2}{|c|}{$\begin{array}{l}\text { 2. Gün } \\
5.7 \mathrm{M} \text {. }\end{array}$} & \multicolumn{2}{|c|}{$\begin{array}{l}\text { 3. Gün } \\
5.8 \mathrm{M} \text {. }\end{array}$} & \multicolumn{2}{|c|}{$\begin{array}{l}\text { 4. Gün } \\
5.8 \mathrm{M} \text {. }\end{array}$} & \multicolumn{2}{|c|}{$\begin{array}{l}\text { 5. Gün } \\
5.8 \mathrm{M} \text {. }\end{array}$} & \multicolumn{2}{|c|}{$\begin{array}{l}\text { 6. Gün } \\
5.8 \mathrm{M} \text {. }\end{array}$} & \multicolumn{2}{|c|}{$\begin{array}{l}\text { 7. Gün } \\
5.8 \mathrm{M} \text {. }\end{array}$} \\
\hline & & $\begin{array}{l}\text { Baş- } \\
\text { lıca }\end{array}$ & $\begin{array}{l}\text { En } \\
\text { Yeni }\end{array}$ & $\begin{array}{l}\text { Baş- } \\
\text { lıca }\end{array}$ & $\begin{array}{l}\text { En } \\
\text { Yeni }\end{array}$ & $\begin{array}{l}\text { Baş- } \\
\text { lıca }\end{array}$ & $\begin{array}{l}\text { En } \\
\text { Yeni }\end{array}$ & $\begin{array}{l}\text { Baş- } \\
\text { lıca }\end{array}$ & $\begin{array}{l}\text { En } \\
\text { Yeni }\end{array}$ & $\begin{array}{l}\text { Baş- } \\
\text { lıca }\end{array}$ & $\begin{array}{l}\text { En } \\
\text { Yeni }\end{array}$ & $\begin{array}{l}\text { Baş- } \\
\text { lıca }\end{array}$ & $\begin{array}{l}\text { En } \\
\text { Yeni }\end{array}$ & $\begin{array}{l}\text { Baş- } \\
\text { lıca }\end{array}$ & $\begin{array}{l}\text { En } \\
\text { Yeni }\end{array}$ \\
\hline \multirow[b]{2}{*}{ Tema } & Yemek & 9 & 8 & 9 & 3 & 10 & 3 & 8 & 7 & 10 & 4 & 10 & 5 & 10 & 3 \\
\hline & $\begin{array}{c}\text { Yemek } \\
\text { Dışı }\end{array}$ & 1 & 2 & 1 & 7 & 0 & 7 & 2 & 3 & 0 & 6 & 0 & 5 & 0 & 7 \\
\hline \multirow{2}{*}{$\begin{array}{l}\text { Kulla- } \\
\text { nıcı }\end{array}$} & $\begin{array}{c}\text { Kişisel } \\
\text { Profil }\end{array}$ & 0 & 0 & 2 & 0 & 1 & 0 & 1 & 0 & 0 & 0 & 0 & 0 & 0 & 0 \\
\hline & $\begin{array}{l}\text { Sayfa } \\
\text { Profili }\end{array}$ & 9 & 8 & 7 & 3 & 9 & 3 & 7 & 7 & 10 & 4 & 10 & 5 & 10 & 3 \\
\hline \multirow[t]{2}{*}{ Çekim } & $\begin{array}{l}\text { Profes- } \\
\text { yonel }\end{array}$ & 5 & 4 & 4 & 0 & 4 & 0 & 2 & 4 & 4 & 1 & 3 & 1 & 7 & 2 \\
\hline & Amatör & 4 & 4 & 5 & 3 & 6 & 3 & 6 & 3 & 6 & 3 & 7 & 4 & 3 & 1 \\
\hline \multirow{3}{*}{$\begin{array}{c}\text { Ön } \\
\text { Planda }\end{array}$} & Yemek & 8 & 4 & 7 & 2 & 8 & 2 & 6 & 4 & 4 & 4 & 8 & 1 & 6 & 2 \\
\hline & Mekân & 0 & 3 & 1 & 1 & 1 & 1 & 2 & 1 & 5 & 0 & 1 & 4 & 2 & 1 \\
\hline & Insan & 1 & 1 & 1 & 0 & 1 & 0 & 0 & 2 & 1 & 0 & 1 & 0 & 2 & 0 \\
\hline \multirow{2}{*}{ Estetik } & Evet & 5 & 3 & 4 & 0 & 4 & 0 & 2 & 3 & 4 & 1 & 4 & 0 & 8 & 1 \\
\hline & Hayır & 4 & 5 & 5 & 3 & 5 & 3 & 6 & 4 & 6 & 3 & 6 & 5 & 2 & 2 \\
\hline
\end{tabular}

Tablonun 2. gününde, 20 paylaşımdan sadece 12'si yemek ile ilgili olmuştur. Bunlardan 2 tanesini kişisel paylaşımlar oluştururken, diğer 10 tanesi sayfa paylaşımlarından oluşmuştur. Çekimlerin 4 tanesi estetik kaygılar göz önüne alınarak profesyonel şekilde çekilmişken, 8 tanesi herhangi bir estetik tasarım olmadan amatör şekilde çekilmişlerdir. 12 paylaşımdan 9 tanesinde vurgu yemeğin kendisindeyken, 2 tanesinde mekanda, 1 tanesinde ise insanın kendisinen kalmıştır.

Tabloya göre 3. günde 13 yemek paylaşımı, 7 tane de yemek dışı paylaşım yapılmıştır. 13 paylaşımdan sadece 1 tanesi kişisel sayfa paylaşımıyken, geriye kalan 12 paylaşım sayfalara ait paylaşımlardan oluşmuştur. Bu paylaşımların 4'ünü profesyonel, geriye kalan 9'unu ise amatör çekimler oluşturmuştur. Yemeği öne çıkaran paylaşım sayısı 10 iken 1 tane mekan, 1 tane de insan paylaşımı ön planda tutulmuştur. 12 fotoğraftan ise sadece 4 tanesinin estetik kaygılarla paylaşıldığı anlaşılmıştır.

Tablonun 4. gününe bakıldığında belirlenen 20 paylaşımdan 15 tanesinin temasının yemek olduğu ve bunlardan da 14 tanesinin sayfalara ait paylaşımlardan oluştuğu anlaşılmıştır. Sadece 6 paylaşımın profesyonel şekilde olduğu tabloda, 5 tanesinin de estetik kaygılar taşıdığı anlaşıımıştır. 15 paylaşım arasından 10 tane yemek, 3 tane mekan, 2 tane de insan vurgusu yer almıştır.

5. günün verilerine bakıldığında 20 adet paylaşımdaki dağılımın 14'ünün yemek, 6 tanesin ise yemek dışı şeklinde olduğu anlaşılmıştır. Yemek ile ilgili 14 paylaşımın tümünü sayfa paylaşımları oluşturmuştur. Bunlardan da sadece 5 tanesi profesyonel çekim şeklinde olmuştur. Paylaşımların 8 tanesinde yemek, 5 tanesinde mekan, 1 
tanesinde ise insan ön planda tutulmuştur. Fotoğrafların 5 tanesinde estetik planlama varken, geriye kalan 9 tanesinde estetik kaygıların olmadı anlaşılmıştır.

Tablonun 6. gününde 20 paylaşımdan 15 tanesinin yemek temasında yer aldığı anlaşılmıştır. 15 paylaşımın tümü sayfalara ait paylaşımlardan oluşurken, bunlardan 4 tanesi profesyonel, 11 tanesi ise amatör çekim şeklinde olmuştur. Yemeği ön planda tutan 9 paylaşım, mekanı vurgulayan 5 paylaşım ve insana vurgu yapan 1 paylaşım olmuştur. Paylaşımların 4 tanesi estetik, 11 tanesi ise estetik değil şeklinde tespit edilmiştir.

Tablonun son gününe gelindiğinde ise toplam 20 paylaşım arasından 13 tanesinin yemek ile ilgili olduğu, 7 tanesinin ise yemek teması dışında kaldığı anlaşıımıştır. Yemek ile ilgili paylaşımların 13'ü de sayfa paylaşımlarından oluşmuştur. Yemek ile ilgili 13 paylaşımın vurgu dağılımı 8 yemek, 3 mekan, 2 insan şeklinde ortaya çıkmıştır. Yemeği tema edinen 13 paylaşımın 9 tanesinde estetik kaygılar güdülmüşken, 4 tanesinde herhangi bir estetik kaygının güdülmediği ortaya çıkmıştır.

Göstergebilimsel açıdan incelenecek görseller, Tema başlığı altında incelenen 140 paylaşımdan yemek ile ilgili olan toplam 99 görsel arasından rastgele örneklem yöntemiyle 'Başlıca' kategorisinden 2, 'En Yeni' kategorisinden 2 olmak üzere toplamda 4 tane örnek seçilmiştir. Görseller, paylaşımı yapan kullanıcının profil sayfası ve profil bilgileri de göz önüne alınarak, yananlam(dolaylı) ve düzanlam(dolaysız) bağlamıyla analiz edilmiştir. 
Tablo 2. Intagram Paylaşımı 1

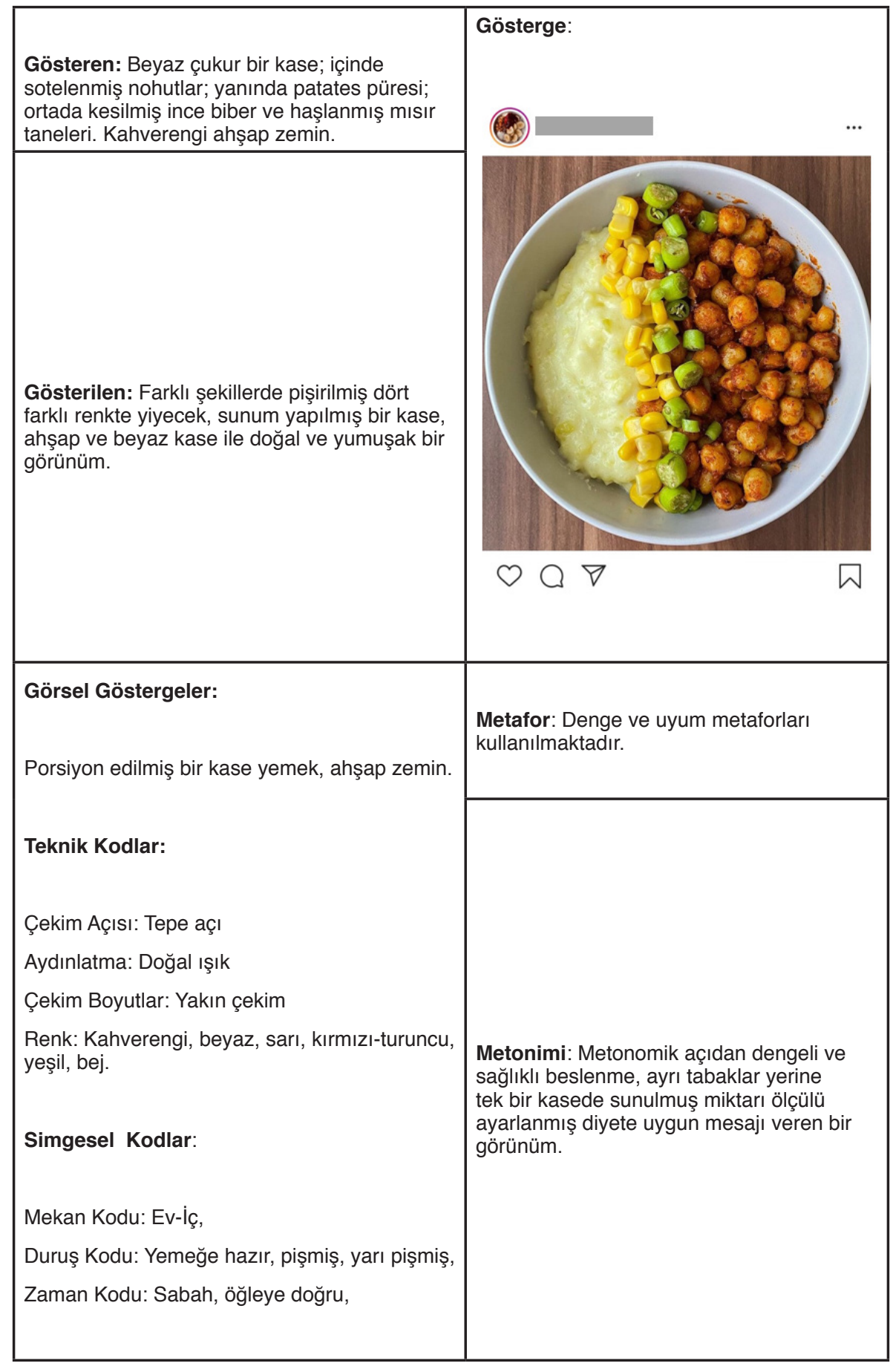


Tablo 3. Intagram Paylaşımı 2

Gösteren: Beyaz düz bir tabak; üstünde mangalda pişirilmiş Adana kebabı, közlenmiş domates ve biber, mangalda pişirilmiş tavuk kanatları, salçalı yağlı ekmek dilimleri ve havuç ve yeşilliklerden oluşan salata malzemeleri, arkada soğan salatası, meze tabağı ve tatlı kaşığı. Siyah örtülü beyaz masa zemini.

Gösterilen: Mangalda pişirilmiş iki farklı et ve közlenmiş yiyecekler, albenili sunum, restoranda yeni servis edilmiş havası verilmiş yapay ışık altında bir görünüm.

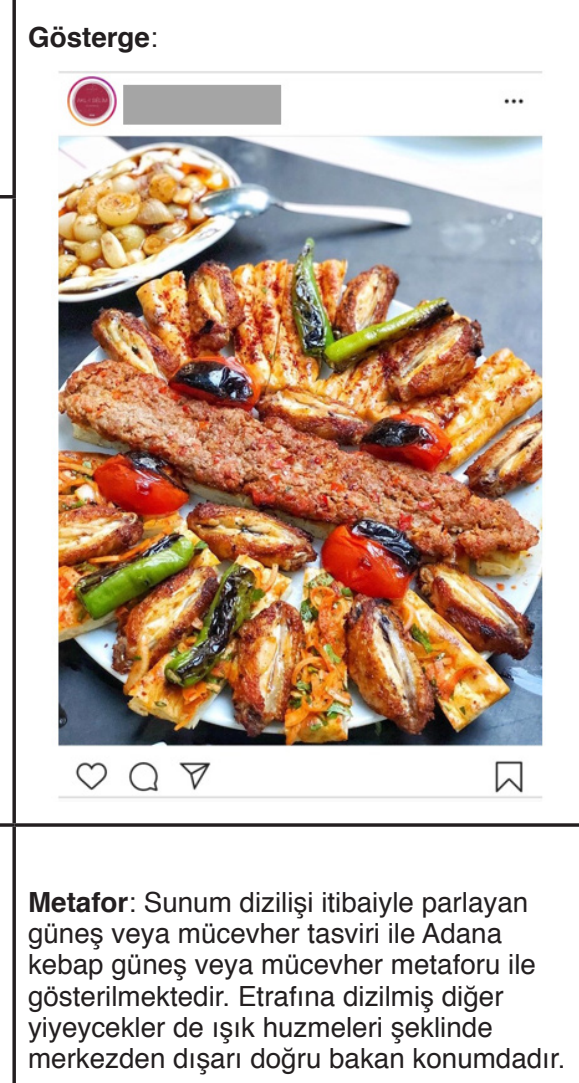

Teknik Kodlar: merkezden dışarı doğru bakan konumdadır.

Çekim Açısı: Üst açı,

Aydınlatma: Yapay ışık,

Çekim Boyutlar: Yakın çekim,

Renk: Siyah, beyaz, sarı, kırmızı-turuncu, yeşil, gri.

\section{Simgesel Kodlar:}

Mekan Kodu: Restoran, İç,

Metonimi: Metonomik açıdan değerlendirildiğinde kebap diğerlerinden daha değerli bir konumda tutulmuş, beynin ödül merkezine hitap eden bir sunum şekli benimsenmiş ve dikkat çekici bir görünüm verilmiştir.

Duruş Kodu: Yemeğe hazır, pişmiş, yarı pişmiş, Zaman Kodu: Akşam, 
Tablo 4. Instagram Paylaşımı 3

Gösteren: Bej kalp şeklinde bir tabak; üstünde kızartılmış köfteler, yanında kızartılmış patlıcan, biber ve domates arkada şamdan tabanı, tül örtü ve tepsi. Mavi camlı beyaz masa zemini.

Gösterilen: Kızartılarak pişirilmiş iki farklı yiyecek, albenili sunum, evde az bekletilmiş ve servis edilmiş, yapay ışık altında bir görünüm.

Görsel Göstergeler:

Servis edilmiş iki tür kızartma, örtülü masa.

\section{Teknik Kodlar:}

Çekim Açısı: Üst açı,

Aydınlatma: Yapay ışık,

Çekim Boyutlar: Yakın çekim,

Renk: Beyaz, mavi, sarı, kırmızı, yeşil, bej.

\section{Simgesel Kodlar:}

Metonimi: Metonomik açıdan değerlendirildiğinde ev ortamında yapılmış kızartma kalp şeklinde tabağa konularak sevgi, yemeği sevme, lezzetli olma, albenili olma durumları vurgulanmıştır.

Mekan Kodu: Ev-i̇ç,

Duruş Kodu: İçmeye hazır, pişmiş,

Zaman Kodu: Akşam, 
Tablo 5. Instagram Paylaşımı 4

Gösteren: İnce belli çay bardağı, çay, çay kaşığı ve tabağı; önünde beyaz tabak üzerine kuru pasta, arkada birinin elinde duran donruma kasesi ve mavi renkli dondurma. Kahverengi, ahşap masa zemini ve pastane ortamı.

Gösterilen: Yeni getirilmiş bir bardak çay, kırıntıların arasında kuru pasta, yeni getirilmiş mavi renkte dondurma yiyen biri, yapay ve doğal bir arada, ışık altında bir görünüm.

\section{Gösterge:}
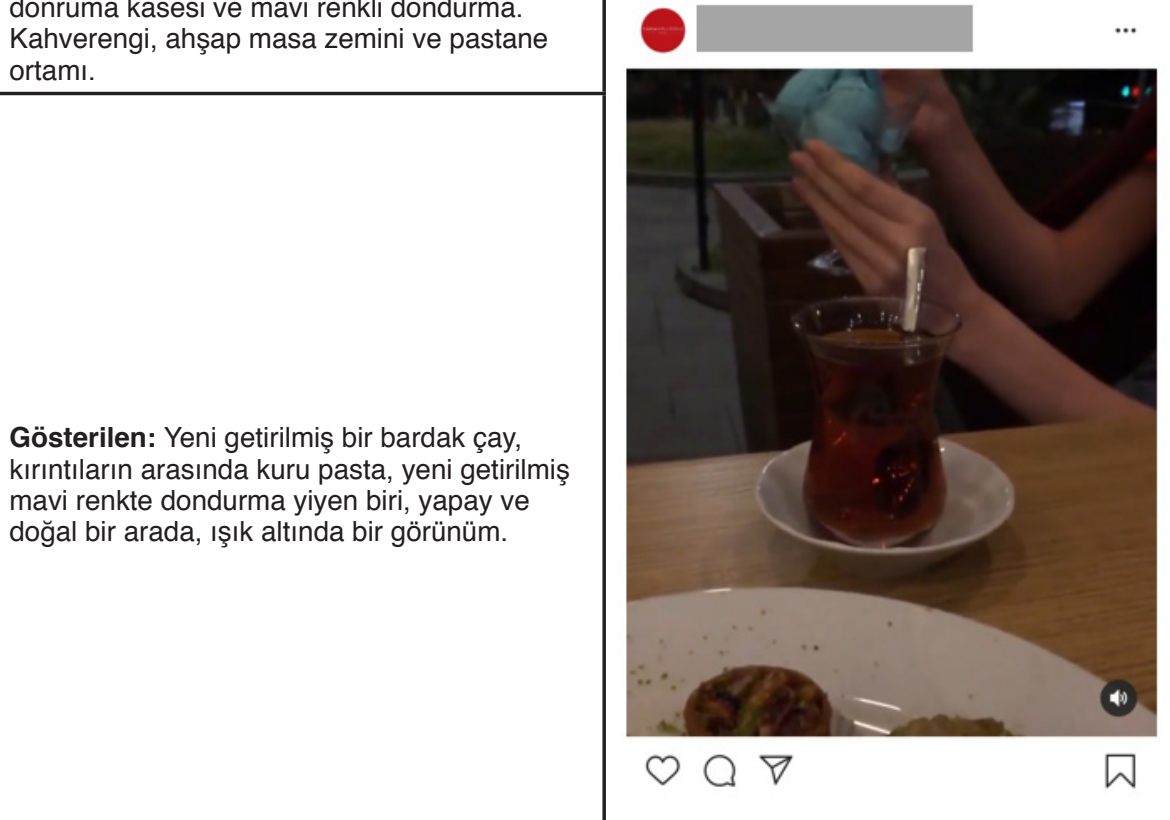

\section{Görsel Göstergeler:}

Servis edilmiş çay, pasta ve dondurma.

Metafor: İnce belli vücut metaforu kullanılmıştır.

\section{Teknik Kodlar:}

Çekim Açısı: Yan-üst açı

Aydınlatma: Yapay-doğal ışık

Çekim Boyutlar: Yakın çekim

Renk: Beyaz, mavi, kahverengi, kırmızı, siyah.

\section{Simgesel Kodlar:}

Mekan Kodu: Pastane, dış.

Duruş Kodu: İçmeye ve yemeğe hazır, pişmiş, Zaman Kodu: Öğleden sonra,

Metonimi: Metonomik açıdan değerlendirildiğinde restoran ortamında yapılmış çay, pasta ve dondurma ile öğleden sonra keyifli bir ortam tasvir edilmiştir. 
İlk iki görsel de 'Başlıca' kategorisinden alınmış sayfa paylaşımlarıdır. Tablo 2'yi paylaşan hesap, sağlıklı bir yaşam vurgusuyla paylaşım yapan ve 2100'ün üzerinde takipçisi olan bir yemek hesabıdır. Görsel incelendiğinde 288 beğeni ve 33 yorum aldığı görülmüştür. Fotoğrafın etkileşim sağladığına işaret eden bu veriler aynı zamanda sayfa sahibinin paylaşım konusunda güncel olduğunu göstermektedir.

Sayfanın profili incelendiğinde tüm paylaşımların Tablo 2'deki tasarımla paylaşıldığı görülmüştür. Sayfaya estetik açıdan katkı sağlayan sağlıklı yemek tabakları, aynı zamanda profesyonel bir görünüm kazandırmıştır. Ancak tabağın sadeliği, yemeklerin rastgele dizilimi ile çatal, bıçak, su, yoğurt veya peçete gibi yemeği görsel açıdan destekleyecek yan ve diyet ürünlerin eksikliği, çekimin profesyonel bir çekim olmadığına işaret etmektedir. Paylaşım, sağlıklı bir yaşam amacıyla yapılmış olmasına rağmen, yemeğe ait pişirme yöntemi, gerekli malzeme listesi ile gıdaların kalori bilgileri eksik bırakıımıştır. Bu ayrıntılar sayfanın profesyonel açıdan eksikliğini göstermektedir. Fotoğraf, profesyonel ortamda çekilmediğinden dolayı, ışı̆̆ın yetersizliği ile yemeğin üzerinde karanlıkta kalan kısımlar, dikkat çeken olumsuz noktaları oluşturmuştur.

Fotoğrafın düzanlamı doğrudan bir yemeği işaret ederken, yananlamı sağlığa gönderme yapmaktadır. Ancak paylaşımda göze çarpan eksiklikler, paylaşımın göstergebilimsel açıdan ve verdiği mesaj bağlamında başarısız olduğunu göstermektedir.

İkinci görsel'e (bk. Tablo 3) bakıldığında ise yine bir sayfa olduğu görülmektedir. Ancak bu sayfa daha çok restoran adına paylaşım yapan ve daha çok bir tanıtım amacıyla kullanılan bir sayfadan oluşmaktadır. 15 bin'den fazla takipçisi olan sayfada bu paylaşım 100 'lerce beğeni ve 10 yorum almıştır. Beğeni sayısının yüksekliği sayfayı takip eden aktif kullanıcı sayısını kanıtlamaktadır. Ayrıca sayfanın profili incelendiğinde tüm içeriklerde yemek vurgusunun yapıldığı anlaşılmaktadır. Sayfanın kullandığı paylaşım sıklığı ve renk tonları ile birbirine uyumlu içerikler, olumlu bir imaj yaratılmasında etkili olmuştur. Tüm içeriklerde mekan ismi ve konumunun etiketlenmesi, yemeklerin canlı renkler ve iştah açıcı şekilde sunulması, mekana müşteri ve takipçi kazandırmak adına olumlu katkı sağlamaktatadır.

Paylaşıma bakıldığında ise çekimlerin rastgele değil, özellikle çekilip paylaşıldığı anlaşılmaktadır. Yemek fotoğraflarının tümünün canlı, parlak reklerle verilmesi, renklerin sıcak renklerden ve kırmızı ile yeşil rengin kontrastından oluşması, fotoğrafların profesyonelliğine işaret etmektedir. Ayrıca her bir fotoğrafta mekanın ismiyle birlikte, yemeğin yanında olması gereken aksesuar ve ek ürünler de yerleştirilmiştir.

Sayfanın sadece yemek veya yemek ile ilgili temalardan oluşan doğrudan paylaşımları vardır. Ancak her bir fotoğrafın iştah açıcı şekilde paylaşılması, yemeği yapan ustaların marifetlerinin sergilenmesi ve her fotoğrafta mekan vurgusunun özellikle yapılıyor olması, paylaşımların müşteride albeni yaratma amacı taşıdığını göstermektedir. Diğer bir ifadeyle mekan, paylaşımlarıyla Instagram kullanan potansiyel müşterilerine tüketim mesajı iletilmeyi amaçlamaktadır.

Analize konu son iki görsel de Instagram \#yemek etiketiyle yapılan aramada 'En Yeni' kategorisindeki kullanıcılara ait görsellerdir. Her iki görselin de kişisel hesaplardan ziyade bir sayfa paylaşımı olduğu anlaşılmaktadır. 
Tablo 4'e bakıldığında ilk göze çarpan tabağın şekli ve yemeğin sunumudur. Yemek bir restoran sunumu değil, evde yapılan bir yemek olarak paylaşılmıştır. Hesabın profili incelendiğinde 6500 takipçi sayısına sahip olduğu ve tüm paylaşımların Tablo 4'teki gibi amatör şekilde çekilmiş ev yemeklerinden oluştuğu anlaşılmaktadır. Sayfanın profil bilgilerinde yemek ile mutfağa dair tutkudan ve yenilikçi fikirlerden, sunumdan bahsediliyor olmasına rağmen, paylaşımlarda bunun karşılığının olmadığı anlaşılmaktadır. Sayfanın bütününün oluşturduğu biçim, profesyonellikten ve estetikten yoksundur.

Tablo 4'teki fotoğrafın çekim açısı, ışıklandırma, yemeği ve sunumu destekleyecek yan öğelerden yoksun olduğu anlaşılmaktadır. Görselin çekildiği açı yanlış olmakla birlikte, fotoğrafta yemek sunumuyla ilgisi olmayan yan öğelerin varlığı, fotoğrafa estetik açıdan bir katkı sağlamamıştır. Aksine altın varaklı, parlak cam yan öğenin temsili zenginlik ve şatafat iken, yemeğin bu temsile uymadığını ortaya çıkartmaktadır.

Sonuç olarak göstergebilimsel açıdan başarısız olan fotoğrafın 11 beğeni ve 1 yorum aldığı görülmektedir. Altmetninde şatafat, lüks ve estetiğin gösterilmeye çalışıldığı fotoğrafta sayfa sahibi, kimliğine 'mutfakta iyi' imajını eklemeyi hedeflemektedir. Ancak kimlik yaratım sürecinde görsel kullanımının ve sayfa bilgilerindeki iddialı ifadelerin uyumsuzluğu, imaj yaratım konusunda başarısız bir profil çizildiğini göstermektedir.

Baklava konusunda söz sahibi olan bir markanın profil sayfasına ait olan Tablo 5 'teki paylaşım bir video paylaşımıdır. Sayfanın tümü incelendiğinde yeni bir hesap olduğu ve resmiyete dair bilgilerin de eksik olduğu anlaşılmaktadır. Bu bilgilerin eksikliği ve sosyal medya hesabının yeni açılmış olması, markanın bilinirliği ve imajı açısından dez avantaj yaratmıştır. Sayfanın bütününe bakıldığında ilk dikkat çeken nokta, birbiriyle uyumsuz paylaşımların oluşturduğu karışıklıktır. Paylaşımların bir kısmı amatör çekimlerden oluşuyorken, diğer bir kısmı ise profesyonel çekimlerden oluşmaktadır. İkisi arasındaki renk, ışık ve netlik farklılıkları, sayfanın bütünselliğine zarar verdiği gibi profesyonelliğine de gölge düşürmektedir.

Paylaşım incelendiğine videonun 52 sn. sürdüğü ve yapılan çekimin ne markanın ne de vurgulanmak istenen yemeğin kendisiyle bir ilgisinin olmadığı, videonun amacının doğru anlaşılmadığı görülmektedir. 6 sn. kadar kısa videoların paylaşıldığı dijital dönemde videonun süresi, amatör çekimi, kurgulanmadan paylaşımı ve konuyla ilgisi olmayacak şekilde ağır çekim efekti, paylaşımın başarısızıı̆ını arttıran etmenleri oluşturmaktadır. Paylaşımın sadece 35 beğeni ve 6 yorum almış olması, tüketici ve takipçilerde tüketim adına albeni yaratmadığını göstermektedir. Ayrıca paylaşımı beğenen kişilerden birinin sayfanın kendisinin olması, sayfaya amatör bir izlenim kazandırmaktadır.

Markanın paylaşımlarına mekanın etiketini ve konumunu eklemesi, takipçi ve tüketici nezdinde imaj yaratımına yöneliktir. Ancak sayfanın bütünü ve Tablo 5 'teki paylaşımın kendisi, yaratılmaya çalışılan imaj ile uyumsuzluk sergilemektedir. Tüketici bağlamıyla albeniden yoksun olan paylaşım, tüketim konusunda da bir eylem doğurmaktan uzaktır.

Dolayısıyla bir alanda söz sahibi olan bir markanın sosyal medya hesabının albeniyi yaratmadığı, özellikle de çalışmaya dahil edilen paylaşımlarla birlikte sayfanın tümünün profesyonellikten ve markanın imajından uzaklığı, sosyal medya hesabı incelendiğinde 
ilk göze çarpan noktaları oluşturmaktadır.

\section{Sonuc}

Tüketim birden çok açıdan ele alınabilecek geniş bir konudur. Hem ekonomik olarak hem psikolojik olarak hem de toplumsal-kültürel bir takım yanları olan derinlikli bir olgu olarak karşımıza çıkmaktadır. Öte yandan tüketim denince yeni dünya düzeninin en önemli parçası olarak da düşünülmektedir (Dal, 2017, s.2). Öyle ki kimi görüşlere göre içinde bulunan toplum yapısında tüketiciler kurumların adeta kendilerine bağımlı hale getirdiği bireylerdir ve tek kaygıları tüketmektir (Şahin, 2009, s.27).

Sosyal medya, milyonlarca insanın haber, bilgi ve eğlence amacıyla hergün kullandığı sınırsız, zamansız ve uluslararası erişim imkanı olan bir alandır. İnsanlar gündelik hayatlarından kesitleri, ilginç buldukları anları, hatta anlamsız buldukları durumları paylaşmaktadır. Tüm hayatını sosyal medya üzerinden takipçilerinin erişimine açan kullanıcılar beğeni, yorum ve taktir edilme beklentisiyle onlarca paylaşım yapmaktadırlar. Yemek de bu paylaşımların bir kısmını oluşturmaktadır. Günlük rutinde önemli bir yeri dolduran yemeğin sosyal medyada paylaşılması, bu platformlardan Instagram'ın sıkça kullanılması rastlantı sonucu değil, Instagram'ın ücretsiz sunduğu imkanlardan ve fotoğraf temelli basit kullanımlı bir uygulama olmasından kaynaklanmaktadır. Kullanıcılar, yemeklerini ve yemek ile ilgili olabilecek her şeyi cep telefonlarından rahatlıkla basit düzenlemelerle paylaşabilmektedirler.

Yapılan çalışmada da görüldüğü üzere \#yemek etiketiyle günlük 6 milyona yakın fotoğraf paylaşılmaktadır. Etiketin amacı olabildiğince çok kişiye ulaşmak olduğundan, paylaşımlar arasında yemek dışındaki konulara da \#yemek etiketinin iliştirildiği anlaşılmıştır. Ancak günlük 6 milyona yakın paylaşımın büyük bir kısmının yemek ve yemek ile ilgili konulardan oluştuğu yapılan çalışmanın mikro ölçekteki örnekleminde ortaya çıkmıştır. Instagram'ın kendisinin otomatik oluşturduğu kategorilerden 'Başlıca'da yemek dışı paylaşımların az olduğu ortaya çıkarken (70/66), 'En Yeni'de yemek dışı paylaşımların daha çok olduğu ortaya çıkmışıı (70/33). Ancak orana bakıldığında yemek ile ilgili paylaşımların daha çok olduğu anlaşılmaktadır. Dolayısıyla günlük 6 milyona yakın paylaşımın bir çoğunun yemek ile ilgili olduğu soncuna ortaya çıkmaktadır.

Yemeğin insanın hayatındaki önemi ve bir çok insanın gündelik hayatlarını sosyal medyada paylaşmaya başladığı dikkate alındığında, yemeğin bunun dışında kalması neredeyse imkansız hale gelmiştir. Sosyal medyanın kimlik, imaj, albeni yaratım, takipçi, beğeni kazanım ve taktir ile onay alım mekanı olduğu düşünüldüğünde, yemeğin de sadece yemek olmaktan çıktığı, yemeğin sosyal medyada bir tüketim nesnesine dönüştüğü anlaşılmaktadır. Yemek ve yemek ile ilgili olan her bir paylaşım ya sahip olduklarının ya sahip olmak istediklerinin ya da sahip olamadıklarının temsiline dönüşmüştür. Yemek bir statü, bir gösteriş ve bir imaj nesnesi halini almıştır. 


\section{Kaynakça}

Arık, E. (2013). Sıradan İnsanın Yükselişi: Sosyal Medya Şöhretleri. Iletişsim ve Diplomasi Dergisi, (1), 97-111.

Barnes, S. B. (2006). A Privacy Paradox: Social Networking in the United States. First Monday, 11(9). DOI:10.5210/fm.v11i9.1394.

Barthes, R. (1979). Göstergebilim Ilkeleri. (B. Vardar; M. Rıfat, Çev.), Ankara: Kültür Bakanlığı Yayınları.

Barthes, R. (1990). Çağdaş Söylenler. (T. Yücel, Çev.), İstanbul: Hürriyet Vakfı Yayınları.

Baudrillard, J. (2017). Tüketim Toplumu, Söylenceleri/Yapıları. (F. K. Hazal Deliceçaylı, Çev.), İstanbul: Ayrıntı Yayınları.

Bayar, A. (2012). Facebooktaki "Mış Gibi" Yaşam Biçimlerinin Yayınlanan Fotoğraflar Üzerinden Çözümlenmesi. E. Dağtaş (Der.). Küreselleşme, Medya, Toplum (s. 319348) içinde. Ankara: BirGün Kitap Yayınları.

Bircan, U. (2013). Roland Barthes ve Göstergebilim. Sosyal Bilimler Araştırma Dergisi, 13(26), $17-41$.

Boyd, D. M. ve Ellison, N. B. (2008). Social Network Sites: Definition, History and Scholarship. Journal of Computer-Mediated Communication, 13(1), 210-230. DOI: 10.1111/j.1083-6101.2007.00393.x

Burnett, R. (2007). Imgeler Nasıl Düşünür? (G. Pusar, Çev.), İstanbul: Metis Yayınları.

Chung, C.F., Agapie, E., Schroeder, J., Mishra, S., Fogarty, J. ve Munson, S. A. (2017). When Personal Tracking Becomes Social: Examining the Use of Instagram for Healthy Eating. 2017 CHI Conference on Human Factors in Computing Systems, (1674-1687). Denver, ABD. DOI: 10.1145/3025453.3025747 Erişim Adresi: https://www.ncbi.nIm. nih.gov/pmc/articles/PMC5432132/

Clement, J. (2020). Most popular social networks worldwide as of July 2020, ranked by number of active users. https://www.statista.com/statistics/272014/global-socialnetworks-ranked-by-number-of-users/ adresinden 24.07.2020 tarihinde erişilmiştir.

Dal, E., N. (2017). Tüketim Toplumu ve Tüketim Toplumuna Yöneltilen Eleştiriler Üzerine Bir Tartışma. Mehmet Akif Ersoy Üniversitesi Sosyal Bilimler Enstitüsü Dergisi, 9(19), 1-21.

Edgar-Hunt, R., Marland, J. ve Rawle, S. (2010). Film Making. London: Ava Publishing.

Eldeniz, L. ve Sepetci, N. (2017). Sosyal Medyada Mahremiyet Algısının Çöküşü "Instagram Üzerine bir Araştırma. E. Balkaş-Erdoğan, N. Tan-Akbulut ve M. ArtuMutlugün (Der). Medyayı Okumak içinde. Istanbul-Ankara: Cinius Yayınları.

Evans, D. (2008). Social Media Marketing: An Hour a Day. New Jersey: Wiley Publishing.

Herhold, K. (2019). How People Interact on Social Media in 2019. https://themanifest. 
com/social-media/how-people-interact-social-media, adresinden 25.07.2020 tarihinde erişilmiştir.

Horzum-Taylor, I. (2015). Facebook and The Being Liked Motive. International Journal of Social Sciences and Education Research, 1(4), 1216-1227. DOI: 10.24289/ ijsser.279131

Işık, M. (2012). Kitle Illetişim Teorilerine Giriş. Konya: Eğitim Yayınevi.

İbrahim, Y. (2015). Instagramming Life: Banal Imaging And The Poetics of The Everyday. Journal of Media Practice, 16(1), 42-54. DOI: 10.1080/14682753.2015.1015800

Kocabay, N. (2014). Sosyal Medyada Günün Menüsü: Sosyal Medyada "Paylaşılan" Yemek Fotoğrafları Üzerine Bir Değerlendirme. Erciyes Iletişim Dergisi, 3(3). DOI: 10.17680/akademia.v3i3.5000006572

Lasén, A. ve Gómez-Cruz, E. (2009). Digital Photography and Picture Sharing: Redefining the Public/Private Divide. Knowledge Technology \& Policy, 22, 205-215.

Leppert, R. (2009). Sanatta Anlamın Görüntüsü, Imgelerin Toplumsal Iş̧levi. (İ. Türkmen, Çev.) İstanbul: Ayrıntı Yayınları.

Manovich, L. (2001). The Language of New Media. USA: MIT Press.

Özcan, B. (2013). Hedonizm ve Kimlik Temeline Dayalı Postmodern Tüketim Yaklaşımı. Sosyoloji Konferansları Dergisi. Sosyoloji Konferansları. http://www. journals.istanbul. edu.tr/tr/index.php/iktisatsosyoloji/article/view/6022/5546 adresinden 28.03.2020 tarihinde erişilmiştir.

Özcan-Demir, N. (2017). Bireylerin Tüketimin Nesnesine Dönüşmesinde, Sosyal Medya Etkisi. Sosyoloji Konferansları, 55(1), 277-288. DOI: 10.18368/iusoskon.328300

Öksüz, B. (2019). Restoranlarda Instagram Kullanımı: Çeşme'deki Restoranlara Yönelik Bir Araştırma. 4th. International EMI Entrepreneurship \& Social Sciences Congress'de sunulan bildiri (s.1037-1313), İstanbul, Türkiye. Erişim Adresi: http://www. emissc.org/files/E-Book/4.\%20EMI\%20FULL\%20TEXT.pdf.

Özdemir, Z. (2015). Sosyal Medyada Kimlik İnşasında Yeni Akım: Özçekim Kullanımı. Maltepe Üniversitesi Illetişim Fakültesi Dergisi, 2(1), 112-131.

Parsa, S. ve Parsa, A. F. (2012). Göstergebilim Çözümlemeleri. İzmir: Ege Üniversitesi İletişim Fakültesi Yayınları.

Salomon, D. (2013). Moving on from Facebook Using Instagram to Connect with Undergraduates and Engage in Teaching and Learning. College and Research Libraries News, 74, 408-412. DOI: 10.5860/crln.74.8.8991

Şahin, Ç. (2009). Tüketim Toplumu: «Mükemmele Evrilen Politika». İçinde E. Dağtaş, B. Dağtaş (Ed.) Medya, Tüketim Kültürü ve Yaşam Tarzları (ss.103-141), Ütopya Yayınevi.

Şener, E. (2012). Instagram'ın Kısa Tarihi (İnfografik). https://sosyalmedya.co/ instagram-infografik/ adresinden 28.03.2020 tarihinde erişilmiştir. 
Şener, G. ve Özkoçak, Y. (2013). Sosyal Ağlarda Görünür Olmak: Facebook Fotoğraflarında Bireyin Kendini Sunum Stratejileri. C. Bilgili ve G. Şener (Der.), Sosyal Medya ve Ağ Toplumu-2, Kültür, Kimlik, Siyaset içinde. İstanbul: Grafik Tasarım Yayınları.

Toplu, M. (2008). Iletişim Teknolojilerinin Gelişimi. http://bgc.org.tr/seminer/iletisimteknolojilerinin-gelisimi.html adresinden 12.09.2018 tarihinde erişilmiştir.

Uysal, A. (2011). Görsel Kültürün ve Sosyo-Kültürel Olguların Öğrenci Resimlerindeki İmgelere Etkileri. Akademik Bakış Dergisi (24), 1-20.

Winson, J. (2013). Photography in The Age of Facebook. Intersect, 6(2), 1-11.

Yetkin-Cılızoğlu, G. ve Aysel, C. (2016). Sivil Toplum Örgütlerinin Instagram Kullanımı. Akademik Sosyal Araştırmalar Dergisi, 4(27), 161-181. DOI: 10.16992/ASOS.1088

\section{Extended Abstract}

Since the first day of the emergence of mass media, communication between individuals, institutions, and states has increased significantly compared to the past. The advancement of technology has brought new communication technologies with it, and all analog methods used in communications processes have been transformed into a digital format. In this digitalization process, traditional media channels have been replaced by digital channels and created new platforms that are recently called social media. Social media, which is based on web 2.0 technology, has turned individuals into users and these users into avatars that can interact with each other. Users can relate to each other, exchange information, and influence each other through their avatars. In this two-way communication process, users can access the content produced or the content they create faster than ever before. They can share and consume content almost unlimitedly in the triangle of time, space, and people.

Among the images, photographs are frequently used in terms of expressing themselves, constructing identity, and satisfying their sense of belonging. Photographs offer users a more comfortable space in terms of directly depicting the current situation. Individuals share photos for the image they want to create and upload their messages that we can make many meanings in the subtext to these photos. Sharing what is consumed, especially as individuals living in the consumption society, convey detailed information about the consumer profile to other users. At this point, sharing of food photographs appears as an element that individuals especially enjoy sharing, can indirectly convey messages about their personal images, and get more appreciation. Food photographs can be shared at different stages of the meal in the form of the recipe, preparation, presentation, and eating of the meal. Giving special recipes in the field of health, making restaurants and businesses feel the ambiance with their food presentations and environments, sharing the meal in crowded or lonely environments can provide users with many reasons for interaction. Among these reasons, identity construction has an important place. Users control their images through these posts. While the content of the shared meal can show the importance given to health by the sharer, 
sharing the meal with an elegant presentation can give information about the skill of cooking or that the people who eat the food are in an expensive consumption. On the other hand, factors such as the shooting of the photograph, the quality of the shooting equipment, and the composition provide information on the professionalism of the shooters.

In this study, food sharing on Instagram, the identity of the person sharing the photo (profile page), the aesthetic concerns carried by the photo, the place where the photo was taken and the tags attached to the post were analyzed in the context of Roland Barthes' semiotic analysis. The sample area of the study was determined as 1 week (7 days) considering the limitations of the article. The data were determined as the total number of posts from the first day of the week to the last day of the week (MondaySunday) in the search made with the tag \#yemek at 00:00, the solstice, every day. In order to keep the most up-to-date of these shares, the last 10 data shared were included in the study.

Shares are analyzed under five main headings. According to this; under the theme title, whether the post is related to the food or a different image shared with the food tag, under the User title, whether the post belongs to the individual user profile, or is it a page opened for financial gain, under the shooting title, the photo / Whether the video is a professional or an amateur shot, under the Foreground title, whether it is the meal itself, a tagged place or a person, under the title of the sharing, whether the sharing is based on aesthetic concerns or randomly. The detailing has been made by looking that it was made. In addition, since the main sharing element of the article is "food", all of the posts under the title of Theme have been discussed, while in the other headings only the posts about food have been taken into account.

As a result, consuming food is an indispensable element for human life as well as sharing it on social media has become just as crucial at this point. Because the foodthemed posts on social media, which are made to be approved and acknowledged, transform food from being an indispensable element of life to a social media consumption object. Sharing food photos on social media can be seen as a demonstration of social status and-or as proof of being included in the desired society. Accordingly, the food is inevitably perceived as a status symbol, image object, or a display item. 